\title{
Hypomagnesaemia and pregnancy
}

\begin{abstract}
Hypomagnesaemia is common in pregnancy, particularly in developing countries and low-income communities. Despite the frequent therapeutic use of magnesium in pregnancy, and the evidence regarding the association of hypomagnesaemia with adverse pregnancy outcomes in animal studies, it remains unclear whether hypomagnesaemia is associated with complications in human pregnancy. Three case reports of pregnancies complicated by moderatesevere hypomagnesaemia are presented and magnesium physiology in pregnancy is discussed. The evidence as to whether hypomagnesaemia may represent a direct cause, a consequence of other disease processes or an epiphenomenon in adverse pregnancies outcomes is reviewed.
\end{abstract}

\section{Keywords}

Hypomagnesaemia, physiology, adverse pregnancy outcomes, hypertensive disorders of pregnancy, diabetes mellitus, premature labour, small for gestational age, Gitelman syndrome, jejunoileal bypass

Date received: 4 August 2017; accepted: 17 October 2017

\section{Introduction}

Magnesium (Mg), the fourth most abundant cation in the body, has been described as the 'forgotten' electrolyte in medicine. $\mathrm{Mg}$ infusions were previously used in pregnancy for tocolysis, and continue to be used for fetal neuroprotection in the setting of prematurity and prevention of eclampsia, as well as oral supplementation for prevention of leg cramps. Maternal hypomagnesaemia (hypo $\mathrm{Mg}$ ) has been reported in $16 \%$ of pregnant women in Nigeria and $40-60 \%$ of pregnant women in South Asia. ${ }^{1,2}$ Murine studies have shown maternal hypoMg is associated with impaired placental development, impaired fetal growth and increased mortality. ${ }^{3,4}$ The evidence that hypoMg is a cause of adverse pregnancy outcome or that supplementation is beneficial in humans remains unclear. Three cases of pregnancies complicated by hypo $\mathrm{Mg}$ are described. $\mathrm{Mg}$ physiology in pregnancy is reviewed, and the possible relationship between hypo $\mathrm{Mg}$ and adverse pregnancy outcomes discussed.

\section{Case I}

A 31-year-old gravida 2 para 1 was referred for antenatal care at 12 weeks' gestation. Diabetes mellitus had been diagnosed at age 20 with hypo $\mathrm{Mg}$, mild renal dysfunction and renal cysts, confirmed on genetic testing to be due to hepatonuclear factor 1 beta heterozygosity (HNF1- $\beta$ ). Her first pregnancy had resulted in the birth of a $3400 \mathrm{~g}$ live male infant at 37 weeks' gestation. The patient's medications included metformin, insulin, folic acid, aspirin and calcium. Sulphonylurea therapy had previously been ineffective. The patient's body mass index preconception was $29.7 \mathrm{~kg} / \mathrm{m}^{2}$. Investigations revealed $\mathrm{HbA} 1 \mathrm{c}$ of $5.3 \%$ and serum creatinine was $84 \mu \mathrm{mol} / 1$ with eGFR $80 \mathrm{ml} /$ $\min / 1.73 \mathrm{~m}^{2}$. During the pregnancy, serum $\mathrm{Mg}$ (se $\mathrm{Mg}$ ) ranged between 0.4 and $0.5 \mathrm{mmol} / 1$ (non-pregnant reference interval $0.7-1.0$ ). Serum potassium (se K) was normal. No $\mathrm{Mg}$ supplementation was given. The current pregnancy was complicated by fetal macrosomia, a healthy $4413 \mathrm{~g}$ infant male born at 37 weeks' gestation who was euglycaemic in the neonatal period.

\section{Case 2}

A 38 -year-old gravida 5 para 2 was noted to have a se $\mathrm{Mg}$ of $0.2 \mathrm{mmol} / 1$ on blood tests performed for investigation of arthralgias at 32 weeks' gestation. Se $\mathrm{K}^{+}$was $3.9 \mathrm{mmol} / 1$ (normal third trimester 3.2-4.6), serum calcium was $2.39 \mathrm{mmol} / 1$ (normal 2.0-2.4) and 25-hydroxy vitamin D was $112 \mathrm{nmol} / 1$ (normal $50-150$ ). The patient was asymptomatic. The woman's first successful pregnancy had been complicated by preeclampsia at 35 weeks' gestation and her second pregnancy was uncomplicated. Se Mg had not been tested previously. The woman's past history was significant for osteosarcoma treated with surgery and chemotherapy including cisplatin at age 19 years. In this pregnancy, gestational diabetes mellitus (GDM) had been diagnosed at 28 weeks and she was treated with metformin and insulin with satisfactory glycaemic control. During the pregnancy se $\mathrm{Mg}$ ranged between 0.2 and $0.4 \mathrm{mmol} / \mathrm{l}$. Twenty-four-hour urine $\mathrm{Mg}$ was inappropriately elevated at $4.1 \mathrm{mmol} /$ day (normal $3-5$ ) and $24 \mathrm{~h}$ urine calcium was $1.0 \mathrm{mmol} /$ day (non-pregnant reference range 1.2-7.5). At 32 weeks' gestation serum aldosterone was $5830 \mathrm{pmol} / 1$ (normal third trimester 415-2800) and plasma renin activity was $138 \mathrm{mU} / 1$ (normal 66-660). Urinary amino acids were of normal pattern. Gene testing for HNF1- $\beta$ was negative. Genetic testing for Gitelman syndrome (GS) is pending. Her electrocardiogram showed normal PR and QRS duration, and the QTc interval was $456 \mathrm{~ms}$. The pregnancy was otherwise uncomplicated, the mother delivering a healthy $3436 \mathrm{~g}$ female infant by planned caesarean section at 38 weeks' gestation. No neonatal electrolytes were performed. The previous cisplatin therapy is the most likely cause of the hypoMg in this case. Cisplatin therapy may cause long-term renal $\mathrm{Mg}$ wasting as well as hypocalciuria. ${ }^{5}$ The main differential diagnosis in this case is GS, which may also cause hypoMg secondary to hypermagnesuria, hypocalciuria and hyperreninaemic hyperaldosteronism.

\section{Case 3}

A 35-year-old El Salvadorian woman, gravida 5 para 0, was noted to have a se $\mathrm{Mg}$ of $0.3 \mathrm{mmol} / 1$ and se $\mathrm{K}$ of $3.1 \mathrm{mmol} / 1$ on routine blood tests at 16 weeks' gestation. The patient was asymptomatic. GDM was diagnosed at 11 weeks' gestation, and her past history was significant for hypothyroidism, vitiligo and non-alcoholic fatty liver disease. She denied using proton pump inhibitors (PPIs), diuretics or herbal treatments, and denied pica or excess caffeine intake. Her se $\mathrm{K}$ had been

Mater Hospital, Raymond Tce, Brisbane, Australia

\section{Corresponding author:}

Adam Morton, Mater Hospital, Raymond Tce, South Brisbane, Brisbane, Queensland 4I0I, Australia.

Email: adam.morton@mater.org.au 
$3.0 \mathrm{mmol} / 1$ six years earlier. Her family history was unknown. Twentyfour-hour urine electrolyte excretion was $\mathrm{Mg} 5.4 \mathrm{mmol} /$ day, calcium $6.6 \mathrm{mmol} /$ day and $\mathrm{K} 75 \mathrm{mmol} /$ day (normal second trimester $10-40$ ). Urine amino acid pattern was normal. Serum aldosterone was $2610 \mathrm{pmol} / \mathrm{l}$ and plasma renin activity $188 \mathrm{mU} / \mathrm{l}$. Antitransglutaminase antibody performed in view of hypothyroidism and vitiligo was negative. As renal ultrasound and function were normal, testing for HNF1- $\beta$ mutation was not performed. $\mathrm{Mg}$ aspartate $1 \mathrm{~g}$ three times a day was prescribed; however, se $\mathrm{Mg}$ remained unchanged. GDM was managed with basal-bolus insulin. A healthy $4179 \mathrm{~g}$ boy was delivered at 37 weeks by elective caesarean section. The mother was lost to follow-up postpartum.

The woman did not have ocular or renal manifestations suggestive of familial hypoMg with hypercalciuria and nephrocalcinosis. Although testing for seven genes associated with Bartter syndrome was negative, this condition is associated with a multitude of gene mutations, some of which are not tested for routinely, and there may be many unrecognised mutations. ${ }^{6,7}$ Bartter syndrome was thought to be the most likely cause of hypoMg in this case.

In summary three cases of different aetiologies of significant hypo $\mathrm{Mg}$ in pregnancy are presented. Despite the severity of hypoMg no maternal or fetal complications other than GDM were noted.

\section{Mg physiology}

Distribution of Mg. The normal adult human body contains approximately $1000 \mathrm{mmol}$ of $\mathrm{Mg}^{8,9}$ The predominant sites of distribution of $\mathrm{Mg}$ are in bone (53\%), muscle (27\%), soft tissue (19\%) and red blood cells (RBCs) $(0.5 \%)$, with only $0.3 \%$ of total body $\mathrm{Mg}$ in serum. ${ }^{10}$ Thirty per cent of the stores of $\mathrm{Mg}$ in bone is exchangeable and functions to stabilise the serum concentration. Of se $\mathrm{Mg}, 20 \%$ is protein bound, $65 \%$ is ionised and the remainder is complexed with anions including phosphate and citrate. Acid-base disturbances have minimal effect on the distribution of $\mathrm{Mg}$. Intracellular $\mathrm{Mg}$ concentrations range from 5 to $20 \mathrm{mmol} / 1$ of which $1-5 \%$ is ionised.

Mg absorption. Mg absorption occurs primarily in the ileum and colon. Fractional intestinal absorption is dependent mainly on $\mathrm{Mg}$ status and tends to be inversely related to intake with $65 \%$ absorption at low and $11 \%$ at high intake. ${ }^{9} \mathrm{Mg}$ intake depends on the $\mathrm{Mg}$ concentration in drinking water and foods. Green leafy vegetables, grain, cereal, nuts and legumes are rich in $\mathrm{Mg}$. Intermittent concentrations of $\mathrm{Mg}$ are found in fruit, meat and fish, and low $\mathrm{Mg}$ concentrations are present in dairy products. Refining and cooking of foods result in significant loss of $\mathrm{Mg} .{ }^{11} \mathrm{~A}$ review of six studies performed in the United States found that $\mathrm{Mg}$ intake during pregnancy ranged from 30 to $50 \%$ of the recommended daily intake of $355 \mathrm{mg} /$ day. ${ }^{12}$ Intake was particularly inadequate in low-income women.

Intracellular $\mathrm{Mg}$ homeostasis is regulated by transport mechanisms and homeostatic factors, which are encoded by $\mathrm{Mg}$-sensitive genes. TRMP6 and TRMP 7 are Mg-sensitive genes localised in the colon and renal distal convoluted tubules. It is thought they play an important role in regulating whole-body $\mathrm{Mg}$ homeostasis. Increased expression of TRMP6 at 12 weeks' gestation has been demonstrated compared with non-pregnant controls indicating an increased demand for $\mathrm{Mg}$ in pregnancy. ${ }^{13}$

Mg excretion. Ninety-five per cent of $\mathrm{Mg}$ filtered by the kidneys is reabsorbed, predominantly in the thick ascending loop of Henle. ${ }^{9,14}$ Reduced absorption, and thus increased $\mathrm{Mg}$ excretion, occurs with increased plasma $\mathrm{Mg}$ concentration, increased glomerular filtration rate, hypophosphataemia and hypercalcaemia. Several hormones including parathyroid hormone, calcitonin, insulin, glucagon and antidiuretic hormone also affect urinary excretion of $\mathrm{Mg}$. Normal $\mathrm{Mg}$ excretion in the non-pregnant adult is $3-5 \mathrm{mmol} /$ day. Urinary excretion of $\mathrm{Mg}$ rises by approximately $25 \%$ during pregnancy. ${ }^{15} \mathrm{In}$ the presence of hypo $\mathrm{Mg}, \mathrm{Mg}$ excretion of greater than $1 \mathrm{mmol} /$ day is consistent with renal $\mathrm{Mg}$ wasting. $\mathrm{Mg}$ excretion of less than $0.5 \mathrm{mmol} /$ day is suggestive of $\mathrm{Mg}$ deficiency. ${ }^{11}$

Assessment of $\mathrm{Mg}$ status. Measurement of se total $\mathrm{Mg}$ levels may be affected by delay in separating serum, high phosphate levels, lipaemia, hyperbilirubinaemia and haemolysis. Se $\mathrm{Mg}$ does not correlate with tissue pools nor reflect total body or intracellular $\mathrm{Mg}$ content. ${ }^{9}$ Measurement of ionised $\mathrm{Mg}$ is possible although susceptible to false results without very well-defined sample handling, and probably has little value in addition to se total $\mathrm{Mg}$ levels. ${ }^{16-21} \mathrm{RBC} \mathrm{Mg}$ does not correlate well with total body $\mathrm{Mg}$ or other measures of $\mathrm{Mg}$ status. ${ }^{22}$ Lymphocyte $\mathrm{Mg}$ may be a better reflection of skeletal and muscle $\mathrm{Mg}$ stores; however, the measurement is technically difficult and has high intra-individual variation. ${ }^{23} \mathrm{Mg}$ loading/tolerance tests are a sensitive measure to detect $\mathrm{Mg}$ deficiency in individuals with normal renal function. ${ }^{24,25}$ Nuclear magnetic resonance spectroscopy is useful as a research tool to measure intracellular $\mathrm{Mg}$ without requiring skeletal muscle or bone biopsy.

$\mathrm{Mg}$ levels in pregnancy. Se $\mathrm{Mg}$ declines from a preconception mean of $0.93 \mathrm{mmol} / 1$ to a nadir mean of $0.63 \mathrm{mmol} / 1$ in the third trimester. $^{15,26-30}$ Trimester-specific reference intervals for $\mathrm{Mg}$ in pregnancy depend on the assay used and the population studied.

Published reference intervals are as follows ${ }^{31}$ :

\begin{tabular}{lllll}
\hline & Preconception & $\begin{array}{l}\text { First } \\
\text { trimester }\end{array}$ & $\begin{array}{l}\text { Second } \\
\text { trimester }\end{array}$ & $\begin{array}{l}\text { Third } \\
\text { trimester }\end{array}$ \\
\hline Se Mg $(\mathrm{mmol} / \mathrm{l})$ & $0.62-0.95$ & $0.65-0.9$ & $0.62-0.9$ & $0.45-0.9$ \\
\hline
\end{tabular}

Similarly ionised and $\mathrm{RBC} \mathrm{Mg}$, and intracellular free $\mathrm{Mg}$ in brain and muscle are lower in pregnancy than in non-pregnant controls when measured by NMR spectroscopy. ${ }^{32,33}$

Transplacental passage of $\mathrm{Mg}$. After the fifth month of gestation, increasing amounts of $\mathrm{Mg}$ are transported from mother to fetus, averaging approximately $4.5 \mathrm{mg} / \mathrm{day} .{ }^{34}$ Fetal $\mathrm{Mg}$ levels are higher than maternal $\mathrm{Mg}$ levels consistent with a transplacental gradient. Little is known about the mechanism and regulation of placental $\mathrm{Mg}$ flux. ${ }^{35}$ It has been postulated that maternal-fetal $\mathrm{Mg}$ gradient is due to an active transport mechanism, as the gradient is not due to differences in protein binding between mother and fetus. ${ }^{36}$ The gradient, however, is insufficient to protect the fetus from $\mathrm{Mg}$ deficiency in the setting of chronic maternal $\mathrm{Mg}$ deprivation.

\section{Hypomagnesaemia and pregnancy complications}

HypoMg has been implicated as a potential contributing factor in hypertensive disorders of pregnancy, GDM, preterm labour and intrauterine growth restriction.

Hypertensive disorders of pregnancy. Meta-analyses have shown an inverse relationship between dietary $\mathrm{Mg}$ intake and the risk of hypertension, stroke, heart failure and diabetes mellitus in the general population. $^{37-39}$ A meta-analysis of 14 studies revealed women with pregnancy-induced hypertension had lower levels of se $\mathrm{Mg}$, zinc and calcium than healthy pregnant women. ${ }^{40}$ There is an overexpression for the gene SLC41A1, a Na/Mg exchanger, in placenta from women with preeclampsia (PET) compared with normal placentas, suggesting a change in $\mathrm{Mg}$ homeostasis may contribute to the development of PET. ${ }^{41}$ Twenty-four-hour urine excretion of $\mathrm{Mg}$ and calcium is significantly lower in second and third trimester in women with mild pregnancy-induced hypertension than in normotensive controls. ${ }^{42}$

Major methodological difficulties in the interpretation of intervention studies into the role of $\mathrm{Mg}$ supplementation in prevention of hypertensive disorders of pregnancy include variations in dietary 
intake of $\mathrm{Mg}$, doses of $\mathrm{Mg}$ used and the bioavailability of individual $\mathrm{Mg}$ preparations used (e.g. $\mathrm{Mg}$ citrate has better bioavailability than $\mathrm{Mg}$ oxide or Mg chloride). ${ }^{43-45}$ High doses of supplemental Mg may result in diarrhoea. A review of the Cochrane Pregnancy and Childbirth Group's trial register found that $\mathrm{Mg}$ supplementation during pregnancy was not associated with a reduction in perinatal mortality, small for gestational age (SGA) or preeclampsia compared with a control group. ${ }^{46}$ Mothers taking $\mathrm{Mg}$ were less likely to require hospitalisation during pregnancy. $\mathrm{Mg}$ supplementation was associated with significantly fewer babies with Apgar score of less than 7 at $5 \mathrm{~min}$, meconium-stained liquor, late fetal heart decelerations and mild hypoxic-ischaemic encephalopathy. A multicentre randomised doubleblind clinical trial, the Brazilian Magnesium trial, is examining the effect of $\mathrm{Mg}$ citrate $150 \mathrm{mg}$ twice a day versus placebo commenced at 12-20 weeks' gestation on adverse pregnancy outcomes in women at higher risk of placental dysfunction. ${ }^{47}$

A recent randomised controlled trial of low-risk pregnant women in Iran with se $\mathrm{Mg}$ less than $0.78 \mathrm{mmol} / \mathrm{l}$ at $12-14$ weeks' gestation found that supplementation with an effervescent $200 \mathrm{mg} \mathrm{Mg}$ preparation for one month together with a multimineral preparation containing $100 \mathrm{mg} \mathrm{Mg}$ until the end of pregnancy was associated with lower risks of PET, intrauterine growth restriction, preterm birth, low birth weight and GDM. ${ }^{48}$

Mouse models of moderate dietary maternal hypo $\mathrm{Mg}$ did not find programming for neonatal nephron deficit or later cardiovascular function at six months of age, suggesting no long-term adverse outcomes for the cardiovascular health on offspring of hypo $\mathrm{Mg}$ mothers. $^{49}$

GDM. The analysis of a possible relationship between se $\mathrm{Mg}$ and the development of GDM has yielded inconsistent results in observational studies. ${ }^{50}$ Studies comparing serum ionised and total $\mathrm{Mg}$ between GDM and controls have revealed lower, similar and elevated levels. ${ }^{51-54}$ Infants of mothers with GDM have lower whole blood $\mathrm{Mg}$ levels at $24 \mathrm{~h}$ of life than matched controls and are at increased risk of neonatal hypocalcaemia. ${ }^{55}$

A double-blind placebo-controlled trial of 70 women with $\mathrm{Mg}$ deficiency and GDM randomised to $250 \mathrm{mg} \mathrm{Mg}$ oxide or placebo per day found that those receiving $\mathrm{Mg}$ therapy had a significant reduction in fasting plasma glucose and serum insulin concentration and improvement in insulin sensitivity, and a lower incidence of neonatal hyperbilirubinaemia and newborn hospitalisation. ${ }^{56}$ No difference was seen in the requirement for insulin therapy, polyhydramnios, preterm delivery, newborn birth size or neonatal hypoglycaemia. In one study of post-partum women following pregnancies complicated by GDM, lower se $\mathrm{Mg}$ was associated with increased risk of developing T2DM. ${ }^{57}$

Preterm labour. Several studies have demonstrated lower se and RBC $\mathrm{Mg}$ levels in women with preterm delivery or preterm labour. ${ }^{58-62}$

SGA. Lower cord blood intracellular platelet Mg levels in SGA neonates suggest that intrauterine $\mathrm{Mg}$ deficiency may result in SGA and potentially programme insulin resistance after birth, leading to increased risk of metabolic syndrome in later life. ${ }^{63}$ The pooled estimation from three trials found that $\mathrm{Mg}$ supplementation was associated with a $30 \%$ reduction in the rate of SGA infants. ${ }^{64}$ Similarly pooled results from four trials found a $33 \%$ reduction in low birth weight with $\mathrm{Mg}$ supplementation, and that overall newborns in $\mathrm{Mg}$ supplementation group weighed $51 \mathrm{~g}$ more than the newborns of non-supplemented mothers.

\section{Medical conditions that cause hypo $\mathrm{Mg}$ and pregnancy outcomes}

The major causes of hypoMg relevant to pregnancy are summarised in Table 1. Diabetes mellitus is likely to be the most common cause of
Table I. Causes of hypomagnesaemia relevant to pregnancy.

Gastrointestinal

- Decreased intake - malnutrition, alcohol excess

- Malabsorption - steatorrhoea, small bowel bypass surgery, proton pump inhibitors, ketogenic diets

- Secretory loss - chronic diarrhoea

Renal

- Congenital tubular defects - Gitelman syndrome, Bartter syndrome, familial hypomagnesaemia with hypercalciuria and nephrocalcinosis, autosomal dominant hypomagnesaemia, HNFI- $\beta$ mutations

- Drug induced - loop/thiazide diuretics, calcineurin inhibitors, previous cisplatin therapy, alcohol

- Reduced $\mathrm{NaCl}$ reabsorption - hyperaldosteronism, hypercalcaemia

- Osmotic polyuria - poorly controlled diabetes mellitus

- Leptospirosis

Miscellaneous

- Post-parathyroidectomy

- Excessive lactation

hypoMg in pregnancy. A Medline review using the terms 'hypomagnesaemia', 'magnesium' and 'pregnancy' indicated that GS was the most common condition associated with hypo $\mathrm{Mg}$ in case studies. Older literature reported hypoMg occurring with thiazide diuretic therapy during pregnancy as well as in pregnancies following jejunoileal bypass surgery for obesity. PPIs, increasingly being prescribed for gastro-oesophageal reflux in pregnancy, may be associated with hypoMg; however, this usually occurs with long-term use and to date no cases have been described in pregnancy.

I. Type I diabetes mellitus (TIDM). Renal clearance of $\mathrm{Mg}$ increases during hyperglycaemia in individuals with T1DM independently of insulin levels from the time of diagnosis. ${ }^{65,66}$ Hypermagnesiuria and hypoMg tend to be greater in female than male individuals with the same glycaemic control. Severity of hypoMg is greater in diabetic patients with microalbuminuria or overt nephropathy than in normoalbuminuric individuals. ${ }^{67,68} \mathrm{~A}$ relationship between maternal se $\mathrm{Mg}$ at approximately nine weeks' gestation and adverse pregnancy outcome (spontaneous miscarriage, congenital malformation) was examined in 96 pregnancies to 84 women with T1DM. ${ }^{69}$ Maternal blood glycohaemoglobin was significantly higher, and se $\mathrm{Mg}$ lower in the group of women with adverse pregnancy outcomes. There was no significant correlation between se Mg and glycohaemoglobin. Amniotic fluid $\mathrm{Mg}$ levels were lower in pregnant women with T1DM compared with gestation-matched controls. ${ }^{70,71}$

Neonatal hypoMg was demonstrated in $40 \%$ of offspring of mothers with T1DM. ${ }^{72}$ These infants did not display the normal increase in se $\mathrm{Mg}$ in the first week of life seen in normomagnesaemic infants. Neonatal hypoMg was related to severity of maternal diabetes mellitus, prematurity and lower maternal gravidity. It is postulated that lower fetal $\mathrm{Mg}$ levels may result in impaired release and resistance to the action of parathyroid hormone resulting in neonatal hypocalcaemia. Less strict glycaemic control during pregnancy in women with T1DM was associated with a higher rate of neonatal hypocalcaemia and lower neonatal se $\mathrm{Mg}$ than in women with strict control. ${ }^{73}$ Similarly se $\mathrm{Mg}$ was lower in venous cord blood in 44 pregnancies to women with diabetes mellitus (27 T1DM, 17 insulin-treated GDM) compared with non-pregnant controls and non-pregnant women with T1DM. Urine excretion of $\mathrm{Mg}$ and calcium is lower in children of mothers with $\mathrm{T} 1 \mathrm{DM}$, possibly related to intrauterine programming of renal bivalent cation handling. ${ }^{74}$

2. GS. GS is an autosomal recessive salt-losing tubulopathy due to a mutation of genes encoding the sodium chloride co-transporters and $\mathrm{Mg}$ channels in the thiazide-sensitive segments of the distal convoluted tubule. The prevalence of GS has been estimated to be $1: 40,000$ women with heterozygote frequency of $1 \%$ in 
Caucasians. ${ }^{75}$ Characteristic biochemical features include hypoMg, hypokalaemia, hyperreninaemic hyperaldosteronism, kaliuresis and hypocalciuria. Thirty pregnancies to 22 mothers with GS have been reported. ${ }^{76-79}$ Pregnancy complications included two cases of stillbirth in women with presumed GS. ${ }^{77,80}$ The diagnosis of GS in these two cases was not definite - both women presented with symptomatic hypokalaemia following gastroenteritis, the se $\mathrm{Mg}$ was normal in both cases, and genetic testing was not performed. Two cases of intrauterine growth restriction, and one case of preeclampsia with haemolysis, elevated liver enzymes and low platelets have been reported in mothers with GS. ${ }^{79}$ In addition, oligohydramnios was noted in six pregnancies that were otherwise uncomplicated. ${ }^{81}$ Despite the treating team being unable to normalise se $\mathrm{Mg}$ and potassium levels in the majority of cases, pregnancy outcomes were normal leading authors to question the necessity of correcting serum electrolytes in GS pregnancies. ${ }^{82-84}$

3. Thiazide diuretic therapy. Thiazide diuretics were extensively used in the treatment of oedema and hypertensive disorders of pregnancy prior to the mid-1980s. Treatment with thiazides in non-pregnant adults was associated with hypo Mg in $19.4 \%$ of 242 subjects after 1-3 weeks of treatment. ${ }^{85}$ Thiazide diuretic use during pregnancy has been shown to be associated with marked hypokalaemia and moderate hyponatraemia; however, se $\mathrm{Mg}$ was not measured. ${ }^{86} \mathrm{~A}$ Cochrane review found no difference between thiazide diuretic use in pregnancy and placebo with regard to the development of PET, perinatal death, preterm birth, gestation at delivery or caesarean section rate. ${ }^{87}$

4. Jejunoileal bypass. Hypo Mg occurs in up to $58 \%$ of patients following jejunoileal bypass ${ }^{88}$ Pregnancy following jejunoileal bypass may be associated with severe hypoMg, hypocalcaemia and hypokalaemic paralysis. ${ }^{89}$ A review of 179 pregnancies in mothers who had previously undergone jejunoileal bypass for obesity found no increased rate of congenital malformations or perinatal mortality, though lower birth weight, shorter gestational age and a higher proportion of small-for-dates infants than expected occurred. ${ }^{90}$ It is possible these mothers may have had other nutritional deficiencies that led to fetal growth restriction.

5. PPIs. HypoMg may uncommonly occur with long-term use of PPI as a result of reduced passive and active intestinal $\mathrm{Mg}$ absorption. While onset of hypoMg has been reported as early as 14 days after commencement of PPI, the median time of onset is after 5.5 years of PPI use, and the risk is highest in the elderly especially with concomitant diuretic use. ${ }^{91,92}$ Short-term PPI use causes at most a $5 \%$ reduction in se $\mathrm{Mg}$ and a $1 \%$ reduction in intestinal absorption after one week of PPI therapy. ${ }^{92}$ No cases of PPI-induced hypoMg in pregnancy have been reported. Studies including more than 10,000 pregnancies with maternal exposure to PPIs did not demonstrate an increased risk of congenital malformation, premature delivery, perinatal mortality, low birth weight or low Apgar scores. ${ }^{93-96}$

6. Calcineurin inhibitors. HypoMg is seen in approximately $5 \%$ of longterm renal transplant recipients, with no significant difference in those receiving cyclosporine or tacrolimus. ${ }^{97}$ No reports of clinically significant hypo $\mathrm{Mg}$ complicating immunosuppression have been reported in pregnancy.

\section{Conclusion}

It remains unclear whether hypo $\mathrm{Mg}$ is a direct cause of adverse pregnancy outcomes, a consequence of underlying disorders such as poorly controlled diabetes mellitus or insulin resistance/metabolic syndrome which may lead to pregnancy complications, or an epiphenomenon in these disease processes. The pregnancy outcome in the three cases presented despite moderate-severe hypoMg, and the predominantly satisfactory pregnancy outcome in women with GS or following jejunoileal bypass argues against hypo $\mathrm{Mg}$ as a direct cause of adverse pregnancy outcomes. The need for $\mathrm{Mg}$ supplementation in hypo $\mathrm{Mg}$ pregnant women who are asymptomatic remains unanswered. Further studies examining the pregnancy and neonatal effects of Mg supplementation in women at high risk of gestational diabetes and hypertensive disorders of pregnancy, and in women with existing diabetes mellitus would be valuable to inform this issue.

\section{Declaration of conflicting interests}

The author(s) declared no potential conflicts of interest with respect to the research, authorship, and/or publication of this article.

\section{Funding}

The author(s) received no financial support for the research, authorship, and/or publication of this article.

\section{Guarantor}

APM

\section{Contributorship}

APM wrote the article.

\section{References}

1. Pathak P and Kapil U. Role of trace elements zinc, copper and magnesium during pregnancy and its outcome. Indian J Pediatr 2004; 71: 1003-1005.

2. Enaruna NO, Ande A and Okpere EE. Clinical significance of low serum magnesium in pregnant women attending the University of Benin Teaching Hospital. Niger J Clin Pract 2013; 16: 448-453.

3. Schlegel RN, Cuffe JS, Moritz KM, et al. Maternal hypomagnesemia causes placental abnormalities and fetal and postnatal mortality. Placenta 2015; 36: 750-758.

4. Almonte RA, Heath DL, Whitehall J, et al. Gestational magnesium deficiency is deleterious to fetal outcome. Biol Neonate 1999; 76: $26-32$.

5. Bianchetti MG, Kanaka C, Ridolfi-Luthy A, et al. Chronic renal magnesium loss, hypocalciuria and mild hypokalaemic metabolic alkalosis after cisplatin. Pediatr Nephrol 1990; 4: 219-222.

6. Subasinghe CJ, Sirisena ND, Herath C, et al. Novel mutation in the SLC12A3 gene in a Sri Lankan family with Gitelman syndrome \& coexistent diabetes: a case report. BMC Nephrol 2017; 18: 140.

7. Sun M, Ning J, Xu W, et al. Genetic heterogeneity in patients with Bartter syndrome type 1. Mol Med Rep 2017; 15: 581-590.

8. Saris NE, Mervaala E, Karppanen H, et al. Magnesium. An update on physiological, clinical and analytical aspects. Clin Chim Acta 2000; 294: 1-26.

9. Jahnen-Dechent W and Ketteler M. Magnesium basics. Clin Kidney J 2012; 5: i3-i14.

10. Swaminathan R. Magnesium metabolism and its disorders. Clin Biochem Rev 2003; 24: 47-66.

11. Fawcett WJ, Haxby EJ and Male DA. Magnesium: physiology and pharmacology. Br J Anaesth 1999; 83: 302-320.

12. Franz KB. Magnesium intake during pregnancy. Magnesium 1987; 6: 18-27.

13. Nestler A, Rylander R, Kolisek M, et al. Blood pressure in pregnancy and magnesium sensitive genes. Pregnancy Hypertens 2014; 4: 41-45.

14. Nair AV, Hocher B, Verkaart S, et al. Loss of insulin-induced activation of TRPM6 magnesium channels results in impaired glucose tolerance during pregnancy. Proc Natl Acad Sci USA 2012; 109: 11324-11329. 
15. Spatling L, Disch G and Classen HG. Magnesium in pregnant women and the newborn. Magnesium Res 1989; 2: 271-280.

16. Sanders GT, Huijgen HJ and Sanders R. Magnesium in disease: a review with special emphasis on the serum ionized magnesium. Clin Chem Lab Med 1999; 37: 1011-1033.

17. Ritter C, Ghahramani M and Marsoner HJ. More on the measurement of ionized magnesium in whole blood. Scand J Clin Lab Invest Suppl 1996; 224: 275-280.

18. Lanzinger MJ, Moretti EW, Wilderman RF, et al. The relationship between ionized and total serum magnesium concentrations during abdominal surgery. J Clin Anesth 2003; 15: 245-249.

19. Johansson M and Whiss PA. Weak relationship between ionized and total magnesium in serum of patients requiring magnesium status. Biol Trace Elem Res 2007; 115: 13-21.

20. Durlach J, Pages N, Bac P, et al. Chronopathological forms of magnesium depletion with hypofunction or with hyperfunction of the biological clock. Magnesium Res 2002; 15: 263-268.

21. Koch SM, Warters RD and Mehlhorn U. The simultaneous measurement of ionized and total calcium and ionized and total magnesium in intensive care unit patients. J Crit Care 2002; 17: 203-205.

22. Elin RJ. Magnesium: the fifth but forgotten electrolyte. Am J Clin Pathol 1994; 102: 616-622.

23. Martin BJ, Lyon TD, Walker W, et al. Mononuclear blood cell magnesium in older subjects: evaluation of its use in clinical practice. Ann Clin Biochem 1993; 30: 23-27.

24. Rude RK. Magnesium metabolism and deficiency. Endocrinol Metab Clin North Am 1993; 22: 377-395.

25. Nadler JL and Rude RK. Disorders of magnesium metabolism. Endocrinol Metab Clin North Am 1995; 24: 623-641.

26. Sheldon WL, Aspillaga MO, Smith PA, et al. The effects of oral iron supplementation on zinc and magnesium levels during pregnancy. Br J Obstet Gynaecol 1985; 92: 892-898.

27. Kisters K. [Disorders of magnesium balance]. Internist 1998; 39: 815-819.

28. Cruikshank DP, Pitkin RM, Reynolds WA, et al. Effects of magnesium sulfate treatment on perinatal calcium metabolism. I. Maternal and fetal responses. Am J Obstet Gynecol 1979; 134: 243-249.

29. Dawson EB, Clark RR and McGanity WJ. Plasma vitamins and trace metal changes during teen-age pregnancy. Am J Obstet Gynecol 1969; 104: 953-958.

30. Lim MK. Experience with serum magnesium estimations. Med $J$ Aust 1969; 1: 1075-1077.

31. Abbassi-Ghanavati $M$, Greer LG and Cunningham FG. Pregnancy and laboratory studies: a reference table for clinicians. Obstet Gynecol 2009; 114: 1326-1331.

32. Resnick LM, Barbagallo M, Bardicef M, et al. Cellular-free magnesium depletion in brain and muscle of normal and preeclamptic pregnancy: a nuclear magnetic resonance spectroscopic study. Hypertension 2004; 44: 322-326.

33. Lim P, Jacob E, Dong S, et al. Values for tissue magnesium as a guide in detecting magnesium deficiency. J Clin Pathol 1969; 22: 417-421.

34. Tsang RC. Neonatal magnesium disturbances. Am J Dis Child 1972; 124: 282-293.

35. Ohata Y, Ozono K and Michigami T. Current concepts in perinatal mineral metabolism. Clin Pediatr Endocrinol 2016; 25: 9-17.

36. Husain SM and Mughal MZ. Mineral transport across the placenta. Arch Dis Child 1992; 67: 874-878.

37. Fang X, Liang C, Li M, et al. Dose-response relationship between dietary magnesium intake and cardiovascular mortality: a systematic review and dose-based meta-regression analysis of prospective studies. J Trace Elem Med Biol 2016; 38: 64-73.

38. Han H, Fang X, Wei X, et al. Dose-response relationship between dietary magnesium intake, serum magnesium concentration and risk of hypertension: a systematic review and meta-analysis of prospective cohort studies. Nutr J 2017; 16: 26.
39. Fang $\mathrm{C}$, Wang $\mathrm{X}, \mathrm{Wu} \mathrm{W}$, et al. Association of serum magnesium level with odds of prediabetes and diabetes in a southern Chinese population: a prospective nested case-control study. Biol Trace Elem Res 2016; 172: 307-314.

40. He L, Lang L, Li Y, et al. Comparison of serum zinc, calcium, and magnesium concentrations in women with pregnancy-induced hypertension and healthy pregnant women: a meta-analysis. Hypertens Pregnancy 2016; 35: 202-209.

41. Kolisek M, Galaviz-Hernandez C, Vazquez-Alaniz F, et al. SLC41A1 is the only magnesium responsive gene significantly overexpressed in placentas of preeclamptic women. Hypertens Pregnancy 2013; 32: 378-389.

42. Singh HJ. Serum and urinary divalent cations and plasma renin activity in women with mild pregnancy-induced hypertension. Med J Malaysia 1995; 50: 93-100.

43. Lindberg JS, Zobitz MM, Poindexter JR, et al. Magnesium bioavailability from magnesium citrate and magnesium oxide. $J \mathrm{Am}$ Coll Nutr 1990; 9: 48-55.

44. Rylander R. Magnesium in drinking water - a case for prevention? $J$ Water Health 2014; 12: 34-40.

45. Firoz M and Graber M. Bioavailability of US commercial magnesium preparations. Magnesium Res 2001; 14: 257-262.

46. Makrides M, Crosby DD, Bain E, et al. Magnesium supplementation in pregnancy. Cochrane Database Syst Rev 2014; 4: CD000937.

47. Alves JG, de Araujo CA, Pontes IE, et al. The BRAzil MAGnesium (BRAMAG) trial: a randomized clinical trial of oral magnesium supplementation in pregnancy for the prevention of preterm birth and perinatal and maternal morbidity. $B M C$ Pregnancy Childbirth 2014; 14: 222.

48. Zarean E and Tarjan A. Effect of magnesium supplement on pregnancy outcomes: a randomized control trial. Adv Biomed Res 2017; 6: 109.

49. Schlegel RN, Moritz KM and Paravicini TM. Maternal hypomagnesemia alters renal function but does not program changes in the cardiovascular physiology of adult offspring. J Dev Orig Health Dis 2016; 7: 473-480.

50. Dalton LM, Ni Fhloinn DM, Gaydadzhieva GT, et al. Magnesium in pregnancy. Nutr Rev 2016; 74: 549-557.

51. Goker Tasdemir U, Tasdemir N, Kilic S, et al. Alterations of ionized and total magnesium levels in pregnant women with gestational diabetes mellitus. Gynecol Obstet Invest 2015; 79: $19-24$.

52. Ertbeg P, Norgaard P, Bang L, et al. Ionized magnesium in gestational diabetes. Magnesium Res 2004; 17: 35-38.

53. Nabouli MR, Lassoued L, Bakri Z, et al. Modification of total magnesium level in pregnant Saudi Women developing gestational diabetes mellitus. Diabetes Metab Syndr 2016; 10: 183-185.

54. Bardicef M, Bardicef O, Sorokin Y, et al. Extracellular and intracellular magnesium depletion in pregnancy and gestational diabetes. Am J Obstet Gynecol 1995; 172: 1009-1013.

55. Banerjee S, Mimouni FB, Mehta R, et al. Lower whole blood ionized magnesium concentrations in hypocalcemic infants of gestational diabetic mothers. Magnesium Res 2003; 16: 127-130.

56. Asemi Z, Karamali M, Jamilian M, et al. Magnesium supplementation affects metabolic status and pregnancy outcomes in gestational diabetes: a randomized, double-blind, placebo-controlled trial. Am J Clin Nutr 2015; 102: 222-229.

57. Yang SJ, Hwang SY, Baik SH, et al. Serum magnesium level is associated with type 2 diabetes in women with a history of gestational diabetes mellitus: the Korea National Diabetes Program Study. J Korean Med Sci 2014; 29: 84-89.

58. Kurzel RB. Serum magnesium levels in pregnancy and preterm labor. Am J Perinatol 1991; 8: 119-127.

59. Mitrovic-Jovanovic A, Dragojevic-Dikic S, Zamurovic M, et al. Comparison of electrolytic status $(\mathrm{Na}+, \mathrm{K}+, \mathrm{Ca} 2+, \mathrm{Mg} 2+)$ in preterm and term deliveries. Clin Exp Obstet Gynecol 2012; 39: 479-482. 
60. Sharma A, Kharb S, Vineeta, et al. Serum magnesium levels in preterm labour in relation to socioeconomic status. Indian J Clin Biochem 1998; 13: 123-125.

61. Kamal S, Sharan A, Kumar U, et al. Serum magnesium level in preterm labour. Indian J Pathol Microbiol 2003; 46: 271-273.

62. Uludag EU, Gozukara IO, Kucur SK, et al. Maternal magnesium level effect on preterm labor treatment. J Matern Fetal Neonatal Med 2014; 27: 1449-1453.

63. Takaya $\mathbf{J}$ and Kaneko K. Small for gestational age and magnesium in cord blood platelets: intrauterine magnesium deficiency may induce metabolic syndrome in later life. J Pregnancy 2011; 2011: 270474.

64. Merialdi M, Carroli G, Villar J, et al. Nutritional interventions during pregnancy for the prevention or treatment of impaired fetal growth: an overview of randomized controlled trials. $J$ Nutr 2003; 133: 1626S-1631S.

65. Djurhuus MS, Skott P, Vaag A, et al. Hyperglycaemia enhances renal magnesium excretion in type 1 diabetic patients. Scand J Clin Lab Invest 2000; 60: 403-409.

66. Roffi M, Kanaka C, Mullis PE, et al. Hypermagnesiuria in children with newly diagnosed insulin-dependent diabetes mellitus. Am J Nephrol 1994; 14: 201-206.

67. Corsonello A, Ientile R, Buemi M, et al. Serum ionized magnesium levels in type 2 diabetic patients with microalbuminuria or clinical proteinuria. Am J Nephrol 2000; 20: 187-192.

68. Allegra A, Corsonello A, Buemi M, et al. Plasma, erythrocyte and platelet magnesium levels in type 1 diabetic patients with microalbuminuria and clinical proteinuria. J Trace Elem Med Biol 1997; 11: 154-157.

69. Mimouni F, Miodovnik M, Tsang RC, et al. Decreased maternal serum magnesium concentration and adverse fetal outcome in insulin-dependent diabetic women. Obstet Gynecol 1987; 70: 85-88.

70. Mimouni F, Miodovnik M, Tsang RC, et al. Decreased amniotic fluid magnesium concentration in diabetic pregnancy. Obstet Gynecol 1987; 69: 12-14.

71. Doraczynska E, Rechberger T, Wawrzycka B, et al. [Concentration of magnesium in the amniotic fluid of a patient with diabetes]. Ginekol Pol 1995; 66: 653-655.

72. Tsang RC, Strub R, Brown DR, et al. Hypomagnesemia in infants of diabetic mothers: perinatal studies. J Pediatr 1976; 89: 115-119.

73. Demarini S, Mimouni F, Tsang RC, et al. Impact of metabolic control of diabetes during pregnancy on neonatal hypocalcemia: a randomized study. Obstet Gynecol 1994; 83: 918-922.

74. Mughal MZ, Eelloo JA, Roberts SA, et al. Intrauterine programming of urinary calcium and magnesium excretion in children born to mothers with insulin dependent diabetes mellitus. Arch Dis Child Fetal Neonatal Ed 2005; 90: F332-336.

75. Knoers NV and Levtchenko EN. Gitelman syndrome. Orphanet $J$ Rare Dis 2008; 3: 22.

76. Morton A, Panitz B and Bush A. Eplerenone for Gitelman syndrome in pregnancy. Nephrology 2011; 16: 349.

77. Nand N, Deshmukh AR, Mathur R, et al. Gitelman syndrome: presenting during pregnancy with adverse foetal outcome. $J$ Assoc Physicians India 2016; 64: 104-105.

78. Moustakakis MN and Bockorny M. Gitelman syndrome and pregnancy. Clin Kidney J 2012; 5: 552-555.

79. Lee M, Kim DI, Lee KH, et al. HELLP syndrome in a pregnant patient with Gitelman syndrome. Kidney Res Clin Pract 2017; 36: 95-99.
80. Lakhi N, Jones $\mathbf{J}$ and Govind A. Fetal demise despite normalisation of serum potassium in Gitelman syndrome. Case report and literature review. Aust $N Z J$ Obstet Gynaecol 2010; 50: 301-302.

81. Mathen S, Venning M and Gillham J. Outpatient management of Gitelman's syndrome in pregnancy. BMJ Case Rep 2013; 2013. DOI: $10.1136 /$ bcr-2012-007927.

82. Basu A, Dillon RD, Taylor R, et al. Is normalisation of serum potassium and magnesium always necessary in Gitelman Syndrome for a successful obstetric outcome? BJOG 2004; 111 : 630-634.

83. Daskalakis G, Marinopoulos S, Mousiolis A, et al. Gitelman syndrome-associated severe hypokalemia and hypomagnesemia: case

report and review of the literature. J Matern Fetal Neonatal Med 2010; 23: 1301-1304.

84. Rusavy Z, Hudec A, Karbanova J, et al. [Gitelman syndrome in pregnancy-a severe hypokalemia with favorable perinatal prognosis]. Ceska Gynekol 2012; 77: 421-423.

85. Pak CY. Correction of thiazide-induced hypomagnesemia by potassium-magnesium citrate from review of prior trials. Clin Nephrol 2000; 54: 271-275.

86. Gjonnaess H. Thiazide treatment in pregnancy with special reference to maternal and foetal electrolytes. Acta Obstet Gynecol Scand 1968; 47: 404-419.

87. Churchill D, Beevers GD, Meher S, et al. Diuretics for preventing pre-eclampsia. Cochrane Database Syst Rev 2007; 24: CD004451

88. Jorgensen S, Olesen M and Gudman-Hoyer E. A review of 20 years of jejunoileal bypass. Scand J Gastroenterol 1997; 32: 334-339.

89. Houston BD and Turner T. Severe electrolyte abnormalities in a pregnant patient with a jejunoileal bypass. Arch Intern Med 1978; 138: $1712-1713$.

90. Knudsen LB and Kallen B. Intestinal bypass operation and pregnancy outcome. Acta Obstet Gynecol Scand 1986; 65: 831-834.

91. Hess MW, Hoenderop JG, Bindels RJ, et al. Systematic review: hypomagnesaemia induced by proton pump inhibition. Aliment Pharmacol Ther 2012; 36: 405-413.

92. Toh JW, Ong E and Wilson R. Hypomagnesaemia associated with long-term use of proton pump inhibitors. Gastroenterol Rep 2015; 3: 243-253.

93. Matok I, Levy A, Wiznitzer A, et al. The safety of fetal exposure to proton-pump inhibitors during pregnancy. Dig Dis Sci 2012; 57: 699-705.

94. Erichsen R, Mikkelsen E, Pedersen L, et al. Maternal use of proton pump inhibitors during early pregnancy and the prevalence of hypospadias in male offspring. Am $J$ Ther 2014; 21: 254-259.

95. Gill SK, O'Brien L, Einarson TR, et al. The safety of proton pump inhibitors (PPIs) in pregnancy: a meta-analysis. $A m J$ Gastroenterol 2009; 104: 1541-1545; quiz 1540, 1546.

96. Pasternak B and Hviid A. Use of proton-pump inhibitors in early pregnancy and the risk of birth defects. N Engl J Med 2010; 363: 2114-2123.

97. Rodrigues N, Santana A, Guerra J, et al. Serum magnesium and related factors in long-term renal transplant recipients: an observational study. Transplant Proc 2017; 49: 799-802. 